\title{
sciendo
}

\section{FALSTAFF"S GLUTTONY, LUST, AVARICE, SLOTH AND PRIDE IN HENRY IV PART I}

\author{
Krste Iliev \\ Faculty of Philology \\ Goce Delcev University, Stip, North Macedonia \\ krste.iliev@ugd.edu.mk
}

\begin{abstract}
This paper aims at looking at Shakespeare`s character Falstaff through the prism of some of the seven deadly sins. The paper doesn't claim that it explores all the sins present in Falstaff's personality. The main sins that this paper examines in Falstaff's personality are the sins of gluttony, lust, avarice, sloth, and pride. The presence of so many sins in the personality of one character that are interconnected is known as concatenation of sins. As Bernard Spivack (1958) and David Wiles (1987) have explained, in many ways Falstaff serves as the Vice figure from the morality plays tempting Prince Hal. Since in the morality plays the Vice figure stems and is associated mainly to the seven deadly sins, this paper will try to show that the fact that Falstaff possesses so many sins can facilitate the possibility of him being identified as stemming from the Vice figure from the morality plays. I will try to find each of the aforementioned sins by analyzing Falstaff actions and inactions and by trying to find characteristics of the sins present in Falstaff 's behavior. This paper will also look at Falstaff 's fate and whether there is any similarity between the fate of the Vice figure in the morality plays and the fate of Falstaff in the second part.
\end{abstract}

Key words: seven deadly sins, concatenation of sins, Vice figure, Falstaff 


\section{INTRODUCTION}

Although critics mainly regard Falstaff as either being, according to Bradly "the humorist of genius" (1965, p.262), or being, according to Stoll "the very stuff of dramatic convention" (1914, p.197 et seq) and miles glorious or being an essentially realistic creation, this paper supports the view of Spivack and Wiles that Falstaff can be regarded in many ways as the Vice figure that tempts Prince Hal. As the figure of Vice has been mostly associated with the seven deadly sins, Falstaff's sins of gluttony, lust, avarice, sloth, and pride present him as being a sort of a Vice figure. Harold Bloom (2017) in his Falstaff: Give me life, describes Falstaff as "the embassy of life" (p.2). However, in my opinion, Falstaff doesn't have any lofty ideals that he would live or die for. For example, Falstaff doesn`t care about honour at all and clearly says it. In my opinion, Falstaff only cares for his basic and brutish instincts, such as eating, drinking, having sex, and of course the necessary evil to achieve these things, money, and of course, queen of all sins, pride. In addition, although most critics describe Falstaff as charming and witty, he is also described as the Vice figure from the morality plays seeking to gain control of a man`s soul and serving as a messenger of the devil and tempter to man. Scott Fraser (2010) summarizes the opinion of the two foremost critics Bernard Spivack and David Wile. The latter sees Falstaff as an embodiment of the Vice figure: "While secularized, the Vice never fully lost its symbolic function in the early modern period." Such a view is influenced by the work of Bernard Spivack, who argues that the Vice's role, "much older than his histrionic title, came into its key position as soon as the martial allegory for the Psychomachia was transformed by the stage into a plot of intrigue" (1958, pp. 140-141). Wiles continues and expands this critical tradition, noting that "vice' is often used as a synonym for fool in the sixteenth century [...] Just as the fool in the Morris dance broke formation and danced where he pleased, so the Vice swept aside the confines of the script" (1987, pp. 4-5). In terms of the relationship between Falstaff and the prince, Wiles points out how Hal refers to him with language drawn from the morality tradition, such as "devil, vice, iniquity, ruffian and Satan, and that Falstaff wields a wooden (as opposed to actual) dagger (1987, p. 122)." I would also argue that Falstaff's charm is a devilish charm and that he acts as a tempter to Prince Hal. Some of the charms that Falstaff uses are the charm of sex, the charm of money, the charm of power and the charm of escape.

\section{FALSTAFF AND THE CONCATENATION OF SINS}

The sin that defines Sir John Falstaff in this play is the carnal sin of Gluttony. Falstaff is presented as eating, drinking, or talking about eating and drinking. However, this is not his 
only sin. Another carnal sin, the sin of lust also haunts Falstaff. This is no surprise as the sins of gluttony and lust are carnal sins and go hand in hand. The connection between gluttony (drunkenness) and lust is encountered in the Bible. In the Genesis, on two subsequent occasions

Lot's two daughters get Lot drunk, have sex with him and become pregnant. In the medieval times, gluttony and lust were regarded as a sin called Security. Thomas Nashe describes this notion in the $16^{\text {th }}$ century: "forgetting mortality. It is a kind of alchemical quintessence a heaven out of earth." $(1593$, p.78) or in other words, guilty carelessness in the ordering of one's moral system. One of the first connections between gluttony and lust in English literature comes from Chaucer`s “The wife of Bath`s Tale". In that play we encounter the phrase "a lickerish mouth must have a lickerish tail" (2011, p.188). The same word, lickerish has different meaning when referring to the mouth and to the tail. When it refers to the mouth, it has the meaning of gluttonous, but when referring to the tail, it means lecherous.

Another example about this connection comes from Humphrey Sydenham, a $17^{\text {th }}$ century sermonizer, who in his Sermons upon solemn occasions (1637) calls gluttony the "forechamber" (p.106) of lust. Jeremy Taylor, a cleric of the Church of England, also pointed to the connection between gluttony and lust. In The Rule and Exercise of Holy Living, Taylor writes:

"1. It [drunkenness] causes woes and mischief, wounds and sorrow, sin, and shame; it makes bitterness of spirit, brawling and quarrelling; it increases rage and lessens strength; it makes red eyes, and a loose and babbling tongue. 2 . It particularly ministers to lust, and yet disables the body; so that in effect it makes man wanton as a satyr, and impotent as age." (1650, p.74)

Last but not least, Shakespeare himself, in the play Macbeth almost half a century earlier that Taylor, made almost the exact point of the link between gluttony, lust, and impotency due to being drunk.

Macduff. What three things does drink especially provoke?

Porter. Marry, sir, nose-painting, sleep, and urine. Lechery, sir, it provokes, and unprovokes; it provokes the desire, but it takes away the performance: therefore, much drink may be said to be an equivocator with lechery: it makes him, and it mars him; it sets him on, and it takes him off; it persuades him, and disheartens him; makes him stand to, and not stand to; in conclusion, equivocates him in a sleep, and, giving him the lie, leaves him.

(Act II, scene 3, lines 787-797) 
In addition, Taylor states: "it [drunkenness] multiplies sins and discovers them;" 1650, p.75). In the case of Falstaff, one of the sins that gluttony provokes is the sin of avarice. The connection between the sin of gluttony and avarice is attested in the Bible, in the Parable about Dives and Lazarus. Dives is a rich man and Lazarus is a poor and sickly beggar who begs at Dives`gate for food. Dives dined sumptuously every day. The issue is not so much that Dives ate sumptuously, but in not sharing his good fortune with the less fortunate and in hoarding food when the poor ones need it. In that case, Dives action and inaction become respectively gluttony and avarice.

The connection between gluttony and sloth is best seen in W. Langland`s Pierce Plowman (1978). The Glutton is presented as vomiting, passing out due to being drunk and after being brought home to his bed, "he had an accidie," (p.55) the archaic, Greek word for sloth, or in other words an attack of sloth.

One learns from Prince Hal in Henry IV Part I that Falstaff thinks only on drinking wine, eating chickens, whores and sleeping. In a few lines, Prince Hal introduced to us several sins that Falstaff possesses namely gluttony (eating and drinking), lust (whores) and sloth (sleeping all afternoon).

Thou art so fat-witted, with drinking of old sack and unbuttoning thee after supper and sleeping upon benches after noon, that thou hast forgotten to115 demand that truly which thou wouldst truly know. What a devil hast thou to do with the time of the day? Unless hours were cups of sack and minutes capons and clocks the tongues of bawds and dials the signs of leaping-houses and the blessed sun himself 120 a fair hot wench in flame-coloured taffeta, I see no reason why thou shouldst be so superfluous to demand the time of the day.

(Act I, scene 2, lines 113-123)

It doesn't take a long time for Shakespeare to expose another sin of Falstaff, namely avarice, the desire for money, which, being a sloth, would ensure that he would enjoy his zest for life: eating, drinking, whores and sleeping. Falstaff himself admits that he is a thief: "Indeed, you come near me now, Hal; for we that take/purses go by the moon and the seven stars, and not/by Phoebus, he,'that wandering knight so fair". (Act I, scene 2, lines 124-129)

Falstaff is even proud to be a thief. He says to Hal: "Why, Hal, 'tis my vocation, Hal; 'tis no sin for a/man to labour in his vocation". (Act I, scene 2, lines 210-211) 
Shakespeare describes a robbery perpetrated by Falstaff and his friends. Robbery is a manifestation of avarice. To make things even more sinful, the gang are attacking a group of pilgrims on their way to Canterbury with "rich offerings" (Act I, scene 2, lines 231). Out of desire for money, Falstaff ruthlessly gives the orders: "Strike; down with them; cut the villains' throats:/ah! whoreson caterpillars! bacon-fed knaves! They/hate us youth: down with them: fleece them" (Act II, scene 2, lines 823-826). However, once the robbery is over, the gang is attacked by a disguised Hal and Poins. The gang, led by Falstaff, quickly escapes. Falstaff here shows moral cowardice, a manifestation of sloth.

As soon as Falstaff gets to the tavern, he instantly demands a drink: "Give me a cup of sack, boy. Ere I/ lead this life long, I'll sew nether stocks and mend/them and foot them too. A plague of all cowards! /Give me a cup of sack, rogue" (Act II, scene 4, lines 1106-1109). However, Falstaff is not satisfied with any kind of wine, and he notices that there is a lime in his wine, a marker of poor-quality wine. According to Thomas Aquinas (1920), studiose, or eating or drinking too daintily is a marker of the sin of gluttony. In addition, wine is always in the back of Falstaff s mind, so he compares cowards to wine with lime:

You rogue, here's lime in this sack too: there is nothing but roguery to be found in villainous man: yet a coward is worse than a cup of sack with lime in it. A villainous coward! Go thy ways, old Jack; die when thou wilt, if manhood, good manhood, be not forgot upon the face of the earth, then am I a shotten herring.

(Act II, scene 4, lines 1114-1120)

Again, with food in the back of his mind, he makes the allusion that if there is any good man in England left, other than him, that he, the fat Falstaff is as skinny as a herring. Still nervous about the outcome of the robbery and angry at Hal and talking to him, Falstaff again demands wine:

You are straight enough in the shoulders, you care not who sees your back: call you that backing of your friends? A plague upon such backing! give me them that will face me. Give me a cup of sack: I am a rogue, if drunk to-day.

(Act II, scene 4, lines 1136-1141)

Hal reminds Falstaff that his lips are still moist from the drink, but Falstaff would not have any of that: 
Henry V: O villain! thy lips are scarce wiped since thou drunkest last.

Falstaff. All's one for that.

[He drinks]

A plague of all cowards, still say I.

(Act II, scene 4, lines 1142-1146)

Falstaff continues with lying about the robbery, stating that they were attacked by a hundred men. Again, Falstaff swears and compares himself with food and says that he is a bunch of radishes if he had not fought him: "All! I know not what you call all; but if I fought/not with fifty of them, I am a bunch of radish" (Act II, scene 4, lines 1173-1174). When Hal catches Falstaff lying, Falstaff again defends himself using food vocabulary:

'Zounds, an I were at the strappado, or all the racks in the world, I would not tell you on compulsion. Give you a reason on compulsion! If reasons were as plentiful as blackberries, I would give no man a reason upon compulsion, I.

(Act II, scene 4, lines 1220-1225)

Falstaff shows that he is a coward once again, which is a sign of sloth, in his conversation with Hal. When they learn that Hal would have to confront on the battlefield Douglas, Percy and Glendower, Falstaff asks Hal whether he is afraid:

But tell me, Hal, art not thou horrible afeard? thou being heir-apparent, could the world pick thee out three such enemies again as that fiend Douglas, that spirit Percy, and that devil Glendower? Art thou not horribly afraid? doth not thy blood thrill at it?

(Act II, scene 4, lines 1349-1355)

When the sheriff comes to the tavern to investigate Falstaff `s robbery, Hal tells Falstaff to hide behind the arras. The conversation between the sheriff and Hal is short, and as soon as the sheriff departs, Peto pulls back the arras finding Falstaff asleep. Falling asleep on such a short notice, when your life is endangered can be viewed as a manifestation of sloth. When Hal and Peto search Falstaff s pockets, they find papers i.e., bill for purchased food and drink:

Peto. [Reads] Item, A capon,.. . 2s. 2d.

Item, Sauce, . . 4d.

Item, Sack, two gallons, 5s. 8d. 
Item, Anchovies and sack after supper, 2s. $6 \mathrm{~d}$.

Item, Bread, ob.

Henry V. O monstrous! but one half-penny-worth of bread to this intolerable deal of sack!

(Act II, scene 4, lines 1525-1531)

In act III, scene 3, Falstaff again confesses that he is slothful, avaricious and lustful. Falstaff knows and admits that he should repent: "Well, / I'll repent, and that suddenly, while I am in some liking;/ I shall be out of heart shortly, and then I/shall have no strength to repent (lines 2011-2014)". Sloth is sin of omission and out of negligence, which is a close translation of acedia (without care) Falstaff never repents. In addition, Falstaff reveals several characteristics about himself that point to his greed (dicing, borrowing money and rarely returning them) and lust (visiting whore houses):

I was as virtuously given as a gentleman need to be; virtuous enough; swore little; diced not above seven times a week; went to a bawdy-house once in a quarter - of an hour; paid money that I borrowed, three of four times;

(Act III, scene 3, lines 2021-2025)

Falstaff continues with his revelations about gluttony and vulgarity (avarice) in his conversation to Bardolph, another member of his gang:

Thou hast saved me a thousand marks in links and torches, walking with thee in the night betwixt tavern and tavern: but the sack that thou hast drunk me would have bought me lights as good cheap at the dearest chandler's in Europe.

(Act III, scene 3, lines 2050-2054)

Falstaff is so prodigal and vulgar that he owes Mistress Quickly money and has to be reminded several times about it. However, either because he is slothful and doesn`t work and simply doesn't have, or because he is mean and niggard, or a combination of these two reasons, he doesn't have the slightest intention of returning the money: Mistress Quickly: "You owe money here besides, Sir John, for your diet and by- drinkings, and money lent you, four and twenty pound" (Act III, scene 3, lines 2081-2083). Falstaff 's response, due to his claim that apparently his pocket has been picked, is that he would not pay anything: "I'll not pay a denier" (Act III, scene 3, line 2088). As soon as Hal says to Falstaff that he has been reconciled with his father, Falstaff's immediate reaction is one of extreme avarice: "Rob me the exchequer the first thing thou doest, and/do it with unwashed hands too." (Act III, scene 3, lines 2191-2192). 
As soon as Hal gives orders to Falstaff, Peto and Bardolph about the incoming battle, and departs, Falstaff demands breakfast from the hostess of the tavern and laments the fact that he should go to war and leave it: "Rare words! brave world! Hostess, my breakfast, come! /O, I could wish this tavern were my drum!" (Act III, scene 3, lines 2215-2217). Even when he is marching to battle, Falstaff does not quit drinking. More to the point, he is a niggard and demands from Bardolph to buy him a bottle of wine:

Falstaff. Bardolph, get thee before to Coventry; fill me a

bottle of sack: our soldiers shall march through; we'll to Sutton Co'fil' tonight.

Lord Bardolph. Will you give me money, captain?

Falstaff. Lay out, lay out.

(Act IV, scene 2, lines 2367-2371)

Falstaff shows his avaricious nature time and again. Even, when it comes to recruiting soldiers, he resorts to bribery in order to turn a blind eye on the suitability of the wealthy to be soldiers. As a result, he describes his army as composed of ragged crooks, dishonest servants and unemployed boys:

I pressed me none but such toasts-and-butter, with hearts in their bellies no bigger than pins' heads, and they have bought out their services; and now my whole charge consists of ancients, corporals, lieutenants, gentlemen of companies, slaves as ragged as Lazarus in the painted cloth, where the glutton's dogs licked his sores; and such as indeed were never soldiers, but discarded unjust serving-men, younger sons to younger brothers, revolted tapsters and ostlers trade-fallen, the cankers of a calm world and a long peace, ten times more dishonourable ragged than an old faced ancient: and such have I, to fill up the rooms of them that have bought out their services, that you would think that I had a hundred and fifty tattered prodigals lately come from swine-keeping, from eating draff and husks.

(Act IV, scene 2, lines 2387-2403)

When the Earl of Westmoreland reminds Falstaff, that the King is waiting for him, Falstaff again responds using a metaphor that is about eating and stealing: "I am as vigilant as a cat to steal cream" (Act IV, scene 2, lines 2427-2428). 
In the middle of the battle, Hal, seeing Falstaff's standing idly, a manifestation of sloth, demands his sword, only to find that Falstaff has a bottle of wine in his holster:

Henry V. Give it to me: what, is it in the case?

Falstaff. Ay, Hal; 'tis hot, 'tis hot; there's that will sack a city.

[PRINCE HENRY draws it out, and finds it to be a bottle of sack]

(Act V, scene 3, lines 2937-2939)

Falstaff openly says that he doesn`t like to have the honour of the heroic sir Walter Blunt, but rather life. A life, of course that consists of robberies, drinking, eating, whoring, sleeping during daytime, cowardice, idleness, lying, taking bribes and, as a consequence, being afraid to die for any cause or anytime:

Falstaff. Well, if Percy be alive, I'll pierce him. If he do come in my way, so: if he do not, if I come in his willingly, let him make a carbonado of me. I like not such grinning honour as Sir Walter hath: give me life: which if I can save, so; if not, honour comes unlooked for, and there's an end.

(Act V, scene 3, lines 2942-2947)

The highest form of cowardice and fear, both manifestations of sloth, with regard to Falstaff happens in Act V, scene 4, when Falstaff pretends that he is dead on the battlefield in order to stay alive, while Hal fights Hotspur and eventually kills him. When Hal sees him, he thinks that Falstaff is dead, however Falstaff rises and out of immense fear stabs the dead body of Hotspur in case he is not dead.

Last but not least, Falstaff is guilty of the sin of pride. Namely Falstaff is a boastful man and a hypocrite. In addition, in his speech on honour, one can see that Falstaff is a nihilist, again a manifestation of the sin of pride according to Henry Fairlie. The Oxford Dictionary of Literary Terms names Falstaff as an example of braggadocio, a cowardly but boastful man. In case he is a soldier, like Falstaff, he is known as miles glorious or vainglorious soldier. Vainglory is one of the daughters of the sin of pride, and later authors usually conflate it with pride and use pride instead of vainglory. Falstaff is also a hypocrite because he claims that he is a brave soldier. However, the reality is that he is a coward as seen at the robbery near Gadshill and on the battlefield. 


\section{CONCLUSION}

By highlighting the association of Falstaff with drinking and eating, with whorehouses, with love of money such as bribery and borrowing, with sleeping during daytime, evading service and cowardice as well as by being boastful, being a hypocrite and entertaining a nihilist point of view of the world, Falstaff proves himself guilty of almost all of the sins and, in my opinion represents a veritable heir to the Vice figure form the morality plays. As Spivack (1958) has suggested, it is hard for us to regard Falstaff as a villain, because Shakespeare has so successfully exploited the comic aspects of Vice. However, even the fate of the "villainous abominable misleader of youth" (Act II, scene 4 , line 1445) coincides also with that of the Vice figure, namely banishment and imprisonment which happens in Henry IV Part II. 


\section{REFERENCES}

Aquinas, T. (1920). Summa Theologica. New Advent.

Bloom, H. (2017). Falstaff: Give me life. Scribner.

Bradley, A.C. (1965). Oxford Lectures. Macmillan and company limited. London.

Chaucer, G. (2011). Canterbury Tales. Collins Classics.

Fairlie, H. (2010). The seven deadly sins today. University of Notre Dame Press.

Nashe,T. (1593). Christ`s Tears over Jeruslem. James Roberts.

Scott Fraser, R. (2010). “The king has killed his heart”. SEDERI Yearbook, nr. 20.

Spivack, B. (1958). Shakespeare and the Allegory of Evil. New York: Columbia Univ.

Press.

Spivack, B. (1958). Moral metaphor and dramatic image in Henry IV, Parts I and II:

Critical Essays. Routledge, 2016.

Stoll, E.E. (1914) Falstaff. Modern Philology, Volume XII.

Sydenham, H. (1637). Sermons upon solemn occasions. Printed by Iohn Beale, for Humphrey Robinson.

Taylor, J. (1650). Rule and Exercise of Holy Living. Printed [by R. Norton] for Richard Royston at the Angel in Ivie-lane, MDCL.

Wiles, D. (1987). Shakespeare's Clown: Actor and Text in the Elizabethan Playhouse. Cambridge University Press. 